\title{
revista limiar
}

\section{Maurício Chiarello*}

\section{Em torno do motivo da despersonalização em T. W. Adorno}

Resumo: $O$ presente trabalho investiga duas temáticas da obra de Adorno estreitamente inter-relacionadas. A primeira diz respeito ao processo de despersonalização em sua relação com a noção de indivíduo. A segunda concerne ao conceito de mímesis. Nesta última, explora-se a ambivalência constitutiva deste conceito, de acordo com a qual o momento mimético de reconciliação com o objeto conjuga-se com o momento mimético de dissolução da identidade do sujeito, ou de sua despersonalização. A compreensão desta ambivalência possui o mérito de iluminar de forma significativa a imagem que Adorno compõe da fisionomia espiritual de Walter Benjamin, apresentada na parte inicial do trabalho.

Palavras-chave: Adorno, T.W. - Benjamin, W. - despersonalização - mímesis experiência estética.

Abstract: This study investigates two themes of Adorno's work closely interrelated. The first concerns the depersonalization process in its relationship to the notion of individual. The second concerns the concept of mimesis. Here we investigate the constitutive ambivalence of this concept, according to which the mimetic moment of reconciliation with the object is combined with the mimetic moment of dissolution of the identity of the subject - or his depersonalization. The understanding of this ambivalence has the merit of clarifying significantly the image that Adorno makes up of Walter Benjamin's spiritual physiognomy, presented in the first part of the study.

Keywords: Adorno, T.W. - Benjamin, W. - depersonalization - mimesis - aesthetic experience.

\footnotetext{
* Doutor pelo Instituto de Filosofia e Ciências Humanas da Universidade Estadual de Campinas, Brasil. E-mail para contato: chiarello@scientiaestudia.org.br .
} 
Assim também não se cansava de esvaziar com um só gesto o manequim de engodo, o eu, para evocar sempre de novo o terceiro elemento, a imagem.

Walter Benjamin ${ }^{1}$

Só o que está morto fornece uma imagem da vida não deformada.

Theodor W. Adorno ${ }^{2}$

A filosofia de Theodor W. Adorno constituiu-se em grande medida na relação estabelecida com o pensamento de Walter Benjamin, num processo de assimilação, crítica e rejeição de motivos de pensamento que se estendeu de 1923 , data em que Adorno conhece aquele que se tornará seu grande interlocutor e amigo admirado, até 1940, ano da morte de Benjamin. A troca de correspondência entre ambos, traduzida e publicada recentemente em nosso país, dá testemunho do quanto esta relação foi intensa, fecunda e decisiva para Adorno. ${ }^{3}$ Outra obra, ainda pouco comentada entre nós, constitui um documento precioso para o estudo não só desta relação de troca recíproca, mas sobretudo para a compreensão do modo como Adorno percebeu e ajuizou a obra de Walter Benjamin - e não só a obra, mas também sua própria pessoa. Trata-se da coletânea Über Walter Benjamin, organizada por Rolf Tiedemann, que reúne escritos de Adorno cujo tema é precisamente Benjamin. Esta coletânea, publicada originalmente em 1970, ano seguinte à morte de Adorno, ainda não foi agraciada com uma tradução brasileira, embora alguns poucos escritos que a compõem já tenham sido publicados de forma isolada em outras obras, como é o caso de Charakteristik Walter Benjamins. ${ }^{4}$

Ora, o estudo do modo como Adorno concebeu Benjamin, a imagem que formou de sua obra e de sua pessoa (os aspectos que lhe pareceram admiráveis ou,

1 “[...] so war Proust unersättlich, die Attrappe, das Ich, mit einem Griff zu entleeren, um immer wieder jenes Dritte: das Bild [...] einzubringen”. Do ensaio “A Imagem de Proust“.

2 "[...] nur das Tote ist das Gleichnis des nicht entstellten Lebendigen". Do aforismo "Para Anatole France”, de Minima Moralia.

3 Com tradução de José Marcos Mariani de Macedo, este volume veio a lume no ano de 2012: AdoRno, T. W. Correspondência 1928-1940 / Adorno-Benjamin. São Paulo: Editora Unesp, 2012.

${ }^{4}$ Este ensaio encontra-se publicado no volume Prismas: Crítica cultural e sociedade, com tradução de Flávio R. Kothe, sob o título "Caracterização de Walter Benjamin”. Na tradução francesa da coletânea, Sur Walter Benjamin, a qual vamos nos referir neste trabalho, o ensaio recebe o título "Port rait de Walter Benjamin”. 
ao contrário, censuráveis), termina por lançar uma luz esclarecedora sobre importantes motivos de pensamento da própria obra adorniana. Assim como aquele que, ao lançar luz sobre um objeto, não deixa de ser por ele iluminado de volta, assim também os traços da fisionomia espiritual de Benjamin que Adorno põe à luz ao procurar caracterizá-la não deixam de revelar, retroativamente, alguns traços decisivos de sua própria filosofia. É com este intuito que propomos aqui, logo de início, uma breve incursão algo descontraída (e por vezes até mesmo pitoresca) por algumas passagens dos escritos que compõem a coletânea Über Walter Benjamin. Uma breve incursão ao longo da qual nossa atenção estará atenta a capturar aqueles traços da fisionomia espiritual de Benjamin que, aos olhos de Adorno, se afiguram particularmente notáveis, entre os quais: seu penchant pelo âmbito do imagético, sua capacidade de atenção micrológica, o frio distanciamento de seu olhar saturnino e, por fim, sua marcante impessoalidade.

\section{Walter Benjamin aos olhos de Adorno}

Deixando de lado a questão de saber o quanto pertence efetivamente a Benjamin a imagem que seu amigo Adorno dele esboça no esforço de caracterização de sua fisionomia, seria interessante observar o quanto os traços dessa imagem resultam de uma projeção de Adorno. Invejada e censurada ao mesmo tempo, esta imagem nos faz pensar em Benjamim como uma espécie de alter ego cuja identidade, embora dotada de grande fascínio, não pôde ser incondicionalmente aceita sob pena de incorrer na transgressão de um interdito.

A feição invejada: a de um pensador que se aventura pela fronteira limítrofe em que a filosofia se avizinha da arte e que, por amor à verdade, corre o risco de não mais poder se chamar filosofia no sentido tradicional do termo. O irracional, o mito, o sonho, a perda da identidade - é por este território do imaginário que se aventura o pensamento de Benjamin, arriscando-se de forma temerária aos olhos de Adorno, a ponto de parecer por vezes, segundo suas próprias palavras, "sucumbir naquilo que Anna Freud denomina de identificação com o agressor, quando se renuncia ao conceito de crítica". ${ }^{5}$ O que delineia a feição temida: a de um pensador que, cedendo ao fascínio da facticidade, termina por permitir que seu pensamento, qual imagens de pensamento, se veja destituído da força de resistência crítica própria das elaborações dialéticas rigorosas. Para Adorno, com efeito, Benjamin transita por uma zona fronteiriça que Ihe parece enfeitiçada. A suspeita de que o gosto pelo domínio das

5 Adorno, T. W. Sur Walter Benjamin. Paris: Gallimard, 2001, p.38. Da recensão de "Sens unique" [“Einbahnstrasse”]. 
imagens se alimente de uma sombria resistência contra o conhecimento racional, esta suspeita constituiu, para Adorno, um motivo de receio certamente bem maior do que para Benjamin.

Benjamin, o feiticeiro. Misto de médium e mágico, Benjamim parecia possuído por forças que escapam ao estrito controle da razão. Podemos fazer uma ideia do fascínio que este pendor pelo âmbito mágico (que inclui a imaginação, o sonho e a fantasia) despertava em Adorno lendo as curiosas linhas de Souvenirs em que procura descrever, em rememoração, a singular fisionomia de seu amigo e a forte impressão que esta lhe causava:

Se devo também evocar sua aparência, então devo dizer que Benjamin tinha qualquer coisa de um mágico, mas não no sentido metafórico do termo, e sim bastante literal. Ter-se-ia podido representá-lo com uma cartola bastante comprida e uma espécie de varinha mágica. Seus olhos eram particularmente notáveis, míopes e muito profundos nas órbitas; deles emanava um olhar meigo e intenso ao mesmo tempo. Seus cabelos, que tinham qualquer coisa de flamejante, eram também muito peculiares. Seu rosto era recortado de maneira bastante simétrica, mas ele possuía, ao mesmo tempo, qualquer coisa - é mais uma vez difícil encontrar a palavra justa para exprimi-lo - de um animal que conserva provisões em suas bochechas. A figura de antiquário e de colecionador marcou, ela também, sua fisionomia. ${ }^{6}$

Adorno descobre no semblante de Benjamin uma admirável semelhança com o semblante de um mágico. Mas nesta admiração também se imiscui, pressentimos, o encanto com a ilusão proporcionada pela magia do artístico, a que o pensamento de Benjamin se entregava sem reservas. Para Adorno, com efeito, Benjamin tinha algo de uma criança incapaz de renunciar à promessa de felicidade e à esperança de redenção de que se encontram imbuídos os contos de fadas: "Quem com ele conversava sentia-se como uma criança que, através do buraco da fechadura da porta trancada, consegue vislumbrar as luzes da árvore de Natal". ${ }^{7}$

Atenção micrológica. Oscilando entre o fascínio e o receio, também é notável a ambivalência de Adorno perante o método de trabalho filosófico de Benjamin. A capacidade de abismar-se sem reserva no múltiplo, dedicando aos objetos da experiência uma atenção minuciosa a ponto de neles se perder (numa espécie de

${ }^{6}$ Idem, p.96.

${ }^{7}$ Idem, p. 11; Adorno, T. W. Prismas: Crítica cultural e sociedade. São Paulo: Ática, 1998, p. 225. 
proximidade mimética que leva à dissolução do sujeito), intentando como que apalpálos e saboreá-los, em busca daquela singularidade extrema que escapa à identidade imposta pelo conceito; a disposição audaciosa de renunciar ao pensamento conceitual estabelecido no anseio de redenção do mais insignificante e desprezível, graças à instauração de uma nova constelação espiritual que Ihe fizesse justiça: isto Adorno admira na experiência de pensamento do amigo. O que receia, em contrapartida: que uma experiência deste teor já não seja mais conceitual no sentido estrito do termo, ou que já não seja constitutiva do que se convencionou chamar de filosofia. Pois ocorre com os objetos de pensamento submetidos a uma atenção micrológica ou filológica extrema como esta, o mesmo que se dá com aqueles objetos que, colocados sob um microscópio tremendamente potente, perdem sua aparência familiar e passam a apresentar uma imagem completamente estranha e inclassificável.

O que poderia garantir o teor de verdade de tais imagens de pensamento? Esta questão afligiu Adorno, para quem tais imagens apresentavam, por vezes, um aspecto singularmente inconsciente ou mesmo naï. A correspondência entre ambos revela 0 quanto Adorno sempre esperou do amigo (e até mesmo exigiu) uma elaboração teórica mais afinada ao materialismo dialético. ${ }^{8}$ Por mais crítico que se mostrasse em relação ao marxismo ortodoxo e à dialética hegeliana, amiúde reclamou da ausência do emprego da categoria de mediação ao avaliar os trabalhos do amigo. Para Adorno, a mediação pelo processo global poderia assegurar que tais imagens fossem mais que meras imagens de um inconsciente arquetípico (míticas ou arcaicas), correspondendo a cristalizações objetivas do processo histórico. Enquanto "imagens dialéticas", possuiriam o condão de captar o anseio coletivo pela superação do modo de produção estabelecido e, destarte, prefigurar a constelação de uma nova ordem social no horizonte da história.

Para aquele que, conhecedor da correspondência entre ambos, sabe da crítica por vezes implacável a que Adorno submeteu os trabalhos de Benjamin, acusando a ausência de mediação pelo processo global, não podem deixar de surpreender algumas passagens com que se depara na Caracterização de Walter Benjamin. Elas soam como o reconhecimento tardio de uma cobrança quiçá indevida, ou como um pedido de desculpas velado que Adorno só foi capaz formular depois da morte do amigo incompreendido. É o que pressentimos, por exemplo, quando lemos:

\footnotetext{
8 Ver, a respeito, o artigo de Luciano GATTI, “Correspondências entre Benjamin e Adorno”, Revista Limiar, vol. 1, n. 2, 2014, pp. 1-47.
} 
O que lhe importa não é recompor a totalidade da sociedade burguesa, mas examiná-la com uma lupa, como alguma coisa que escapa à vista, uma coisa natural, uma chose diffuse. Seu método micrológico e fragmentário nunca assimilou totalmente a ideia da mediação universal que, tanto em Hegel como em Marx, institui a totalidade. Imperturbavelmente, ele permaneceu fiel a seu princípio segundo o qual a mais ínfima parcela de realidade percebida vale mais que o resto do mundo. ${ }^{9}$

Contudo, mesmo então, dez anos após a morte do amigo, não deixa de parecer questionável a Adorno o método de trabalho empregado por Benjamin. Não deixa de recear ele que as mais ínfimas parcelas de realidade sobre as quais recai sua atenção micrológica, que os inúmeros fragmentos (em forma de citações literárias) recolhidos e postos em relação recíproca, num trabalho de montagem em mosaico, possam falar por si mesmos, liberados de toda argumentação teórica. Assim é que, pouco mais adiante, neste mesmo ensaio, Caracterização de Walter Benjamin, sentencia ele: "A filosofia do fragmento permaneceu ela mesma fragmentária, vítima de um método que talvez - nada pode garanti-lo - não seja de todo aplicável ao pensamento". ${ }^{10}$

A avaliação que Adorno realiza do legado de Benjamin, num aforismo de Minima Moralia datado de 1945, é bem característica desta renitente ambiguidade a respeito do método de trabalho do amigo. O legado de Benjamin, sintetiza ele ao final deste aforismo, consistiria na obrigação de pensar ao mesmo tempo dialética e não dialeticamente. ${ }^{11}$ Saibamos ler nas entrelinhas. Afinal, esta obrigação encerra duas exigências opostas não facilmente conciliáveis. A exigência de pensar não dialeticamente, isto é, de voltar-se para os resíduos e pontos sombrios que escaparam à dialética, e que por isso aparecem como insignificante ou desprezível às leis da dinâmica histórica, esta exigência é genuinamente de Benjamin. Em contrapartida, a exigência de pensar dialeticamente, isto é, de recuperar pelo conceito (quiçá graças à mediação do processo global auferida pela dialética) o que esta mesma dialética desprezou como sendo insignificante ou marginal, esta exigência foi, em grande medida, imposta por Adorno a Benjamin.

E, no entanto, apesar desta exigência em grande medida não atendida, o célebre último aforismo de Minima Moralia rende um tributo inegável ao pensamento

\footnotetext{
9 Adorno, T. W. Sur Walter Benjamin, op. cit., p. 22; Adorno, T. W. Prismas, op. cit., pp. 231-2.

${ }^{10}$ Idem, p. 26; Idem, pp. 235.

${ }^{11}$ Ver o aforismo “Legado”: AdoRno, T. W. Minima Moralia. São Paulo: Ática, 1993, p. 131-4.
} 
de Benjamin e ao valor inestimável que sua obra apresenta para Adorno - muito embora este aforismo não faça referência direta a Benjamin em momento algum, o que dá o que pensar. Resumidamente, lemos neste aforismo que a filosofia ainda digna de seu nome seria a tentativa de considerar as coisas tais como se apresentariam do ponto de vista da redenção. Sua tarefa consistiria em produzir perspectivas nas quais o mundo se mostre indigente e deformado, tal como um dia aparecerá sob a luz messiânica. ${ }^{12}$ Ora, esta "filosofia ainda digna de seu nome" não é outra senão a filosofia de Benjamin - ou, ao menos, a filosofia de Benjamin tal qual estimada por Adorno. Isto fica especialmente patente quando cotejamos este aforismo com a passagem final da Caracterização de Walter Benjamin, na qual lemos: "o cerne da filosofia de Benjamin é a ideia de redenção [messiânica] de tudo que está morto, enquanto restituição da vida deformada pela reificação, à qual ela mesma não pode escapar". ${ }^{13}$ Sim, o legado de Benjamin possui para a obra adorniana uma relevância que não devemos subestimar de forma alguma, por mais crítico que o próprio Adorno tenha se mostrado para com ele - ou talvez justamente por isso. Inegavelmente, sua filosofia terminou por incorporar não poucos motivos de seu pensamento, ainda que não o tenha assumido abertamente.

O motivo da despersonalização em Benjamin. Há um traço da personalidade de Benjamin que se afigura marcante para Adorno. Este traço encontra correspondência com o motivo da despersonalização presente na Teoria Estética adorniana, e justamente por isso aqui nos interessa explorá-lo mais detidamente. ${ }^{14}$

Benjamin dava a impressão de não ser uma pessoa no sentido existencial do termo, escreve Adorno, dava a impressão de não ter corpo, de ser estranho à própria physis. Era um espírito tão alheio a si mesmo, tão distante da vida imediata, que Adorno chega a sugerir que pudesse possuir traços de esquizofrenia. Não era propriamente um esquizofrênico, ressalva Adorno, mas a experiência deste radical alheamento de si teria sido fundamental para o desenvolvimento de seu projeto filosófico.

Para Adorno, com efeito, a fecundidade de seu projeto filosófico teria resultado dessa confluência entre a alienação social reinante e a alienação experienciada em si

\footnotetext{
${ }^{12}$ Ver o aforismo "Para terminar": AdoRno, T. W. Minima Moralia. op. cit., pp. 215-6.

${ }^{13}$ Adorno, T. W. Sur Walter Benjamin, op. cit., p. 29; Adorno, T. W. Prismas, op. cit., pp. 237. Recomendamos ao leitor que realize ele mesmo uma comparação minuciosa das passagens acima mencionadas, que aqui não empreendemos por força de concisão. Não há como deixar de se admirar com a extraordinária semelhança existente entre elas.

${ }^{14}$ A caracterização a que vamos nos referir encontra-se no ensaio "Benjamin, o epistológrafo". Cf. ADORNo, T. W. Sur Walter Benjamin, op. cit., pp. 74-84.
} 
mesmo. Sua pessoa era como médium de sua obra: "Ele quase não aparentava ser uma pessoa, mas sim um teatro sobre o qual se manifestava uma verdade que buscava alcançar a linguagem por seu intermédio". ${ }^{15}$ Experimentando a liquidação do eu, sua pessoa pôde se apresentar como uma espécie de teatro de processos objetivos, à semelhança do que ocorre no processo de alienação vigente na sociedade atual, em que cada indivíduo se vê reduzido à mera função predeterminada de uma organização burocrática (ou mera engrenagem de uma maquinaria tecnocrática que Ihe escapa por completo), não podendo mais se considerar uma pessoa no sentido pleno do termo, ou não mais possuindo o direito de falar de si como pessoa.

Justamente isto logra captar o olhar saturnino de Benjamin: sua percepção quebra o encanto de uma individualidade que nutre a ilusão de ser autônoma e soberana. O sujeito, tal qual definido pelas categorias de autonomia, de totalidade, de sistema e de vida herdadas da metafísica subjetivista, tal sujeito desaparece de sua filosofia. Nas palavras de Adorno, sua filosofia contemplava o mundo do ponto de vista dos mortos e era capaz de falar como falam os mortos.

Eis o motivo do olhar petrificante de medusa: o olhar que desvela a morte no que aparenta estar vivo. Ora, este motivo que Adorno reconhece atuante em Benjamin é precisamente o motivo que Adorno valoriza na experiência estética autêntica, manifesta na arte de vanguarda de seu tempo: o motivo do encantamento que desencanta ao instilar a morte no que ostenta estar vivo. Tomemos as últimas e comoventes sentenças do breve necrológio que Adorno fez publicar no jornal Aufbau no dia 18 de outubro de 1940, três semanas após a morte de Benjamin, sob o título Em mémoire de Benjamin:

Mas ele agora se perdeu, este olhar que contemplava o mundo do ponto de vista dos mortos. Como se o mundo sob o sol se mantivesse ali, diante dele, na escuridão: o mundo é tal qual aparece aos olhos daqueles que desapareceram, exatamente assim. Este olhar mortalmente triste dispensou, sem jamais se esgotar, todo seu calor e toda sua esperança para a vida enregelada ${ }^{16}$.

Em consonância com esta caracterização e buscando completar os traços da fisionomia espiritual que Adorno delineia de seu amigo, valeria ainda referir-se à seguinte passagem da Caracterização de Walter Benjamin, escrito a propósito do décimo aniversário da morte de Benjamin:

\footnotetext{
${ }^{15}$ AdORnO, T. W. Sur Walter Benjamin, op. cit., p. 74.

${ }^{16}$ Idem, p. 87.
} 
Poder-se-ia dizer que todo seu pensamento emana da 'história natural'. Os elementos petrificados, enregelados ou obsoletos da cultura, todo fenômeno cultural que perdeu seu colorido vital fascinavam-no da mesma forma como a um colecionador que se sente atraído por um fóssil ou por uma planta conservada num herbário. Entre seus objetos prediletos estavam as bolas de vidro contendo uma paisagem sobre a qual se faz nevar com uma sacudidela. Poder-se-ia inscrever a expressão francesa nature morte encimando o portal que conduz aos labirintos secretos de sua filosofia. [...] O que the interessa não é somente despertar a vida fossilizada - como na alegoria -, mas antes considerar as coisas vivas como se já pertencessem a um passado longínquo, à história primitiva, para que assim revelassem bruscamente sua significação. A filosofia incorpora em si o fetichismo da mercadoria: como por encantamento, tudo deve se transformar em coisa para conjurar o horror da coisificação. ${ }^{17}$

Desta passagem, retenhamos a seguinte sentença notável, sobre a qual nos deteremos mais adiante: "o que lhe interessa não é somente despertar a vida fossilizada, mas antes considerar as coisas vivas como se já se encontrassem fossilizadas".

Outro traço marcante da personalidade de Benjamin, para Adorno, consiste na falta de proximidade e de calor humano que se sentia em sua presença. A este respeito, escreve Adorno numa passagem de Souvernirs:

Não se trata aqui da imagem corriqueira da pretensa frieza intelectual. Era, antes, como se ele houvesse pago um preço terrível pela violência metafísica do que havia vislumbrado e buscava exprimir por meio de palavras indefectíveis. Como se falasse, por assim dizer, como um morto. Como se houvesse pago um preço por conhecer calma e singelamente coisas que aos vivos não é dado conhecer normalmente ${ }^{18}$.

\footnotetext{
${ }^{17}$ Idem, p. 16; ADORNo, T. W. Prismas, op. cit., pp. 228. Era, de fato, notável o fascínio que despertavam em Benjamin as coisas e as obras desaparecidas aos olhares que um dia lhes foram familiares, no passado longínquo. A passagem do tempo, ao contrário de tornar estas obras mais estranhas e anacrônicas, ou definitivamente datadas, passava a dotá-las de singular beleza. Como se o tempo laborasse qual artista talentoso capaz de dotar a obra original de uma beleza que o artista original não lograsse jamais atingir em seu tempo: a beleza de uma promessa de felicidade que não se cumpriu - e que ao crítico cumpria buscar decifrar inapelavelmente.

${ }^{18}$ Idem, p. 97.
} 
Relacionado a este traço característico de falta de proximidade, Adorno observa que, mesmo ao falar, Benjamin parecia escrever. O espírito era para ele o mais imediato. Sua preferência dileta pelas cartas explicar-se-ia, destarte, pelo fato de proporcionarem relações interpessoais mediatizadas. Poderíamos ainda observar que os traços de epistológrafo, que Adorno salienta em Benjamin em sua descrição, remetem aos de um artista. Cultivando a arte de escrever cartas, Benjamim parece antes cultivar a arte da escrita. Suas cartas são marcadas pelo ritual de uma composição artística e são notáveis pelo seu valor literário. ${ }^{19}$

Feito este apanhado sumário dos traços mais marcantes da fisionomia espiritual de Walter Benjamin, tais como se apresentavam aos olhos de Adorno - e observando que estes traços denotam por vezes um caráter intrigante e paradoxal -, podemos delinear da seguinte maneira a proposta deste trabalho. Buscar compreender o paradoxo que se estabelece entre o frio distanciamento do olhar saturnino, que vislumbra a morte em tudo o que se afigura estar vivo, e o poder de atenção micrológica deste mesmo olhar, capaz de captar a expressão vital do que parecia morto de tão inexpressivo, acolhendo calorosamente o ser mais insignificante em busca de sua redenção. Paradoxo este expresso de forma admirável pela sentença formulada por Adorno ao caracterizar o olhar de Walter Benjamin como sendo "um olhar mortalmente triste, mas capaz de dispensar todo seu calor e toda sua esperança para a vida enregelada, sem jamais se esgotar".

No que segue, faremos inicialmente uma exposição da noção de despersonalização tal como elaborada pela dialética adorniana. Veremos que esta noção apresenta a mesma ambivalência que deslindamos na caracterização de Benjamin realizada por Adorno. Em seguida, procuraremos mostrar como a ambivalência constitutiva do movimento de duplo sentido característico, segundo Adorno, do pensamento de Benjamin (contemplar as coisas vivas do ponto de vista dos mortos e, no mesmo movimento, acolher calorosamente a vida enregelada) corresponde a uma ambivalência que é própria do conceito adorniano de mímesis.

\footnotetext{
${ }^{19}$ Ver o ensaio “Benjamin, o epistológrafo”, escrito em 1965 (ADORNo, T. W. Sur Walter Benjamin, op. cit., pp. 74-84).
} 


\section{O horror da despersonalização}

O termo personalidade pode recobrir diversos sentidos, entre os quais: 1) pessoa digna de respeito, venerada ou cultuada, distinta por sua importância; 2) traço característico ou marcante da individualidade de uma pessoa, que a torna distinta das demais; 3) a própria individualidade da pessoa, sua identidade própria ou característica. Em todos os sentidos designados, porém, a identidade do sujeito consigo mesma é afirmada como característica própria e definida, seja em sua dimensão psicológica, seja no plano de reconhecimento social.

Ora, o questionamento da noção de indivíduo, notadamente de indivíduo cuja autenticidade se baseia na identidade consigo mesma, valorizada como sua personalidade, é questionamento dos mais fundamentais no pensamento adorniano, e que requer cada vez mais ser bem compreendido. Esta observação, que não é nossa, mas de Jeanne Marie Gagnebin ${ }^{20}$, subscrevemo-la aqui integralmente por seu acerto e pertinência. Com efeito, em conjunto com a noção de personalidade, a noção de indivíduo constitui uma questão das mais essenciais na obra de Adorno e, ao mesmo tempo, das mais problemáticas e difíceis. Talvez não haja questão mais espinhosa e paradoxal. Para dar uma ideia, desde logo, do caráter paradoxal que assumem estas noções na dialética adorniana, bastaria dizer que, de um lado, o sujeito que afirma cegamente sua personalidade como identidade empedernida promove, a sua revelia, sua própria despersonalização; por outro lado, aquele sujeito que acolhe um momento de dissolução de sua identidade, promotor de despersonalização, logra conquistar uma personalidade mais verdadeira. Assim, para salvaguardar a própria identidade, o sujeito deve redimir-se do próprio eu: como entender este movimento paradoxal? Como procuraremos fazer ver a seguir, na medida em que a noção de personalidade apresenta um sentido ora positivo ora negativo, para Adorno, o motivo da despersonalização termina por refletir esta ambivalência em sua obra.

Buscando compreender o motivo da despersonalização em Adorno, seria preciso notar que ele se desenvolve num limite tênue delineado entre o personalismo e a impessoalidade. Bem ao gosto de suas reversões dialéticas, Adorno se posiciona tanto a favor como contra a despersonalização. Entendamos: a favor de uma

\footnotetext{
${ }^{20}$ Ver o artigo "Atenção e dispersão: elementos para uma discussão sobre arte contemporânea a partir de Adorno e Benjamin”. In Limiar, aura e rememoração: Ensaios sobre Walter Benjamin, São Paulo: Editora 34, 2014, p. 100.
} 
despersonalização que solape o personalismo ostensivo, mas contra uma despersonalização que redunde na mera impessoalidade, ou na pura anonimia. ${ }^{21}$

Quando se posiciona contra o personalismo, Adorno se coloca contra a afirmação de uma identidade abstrata, isto é, de uma identidade aparente que se conforma ao papel social que cada um de nós é levado a assumir na sociedade capitalista, em prol de sua sobrevivência e auto conservação. Este personalismo artificial, o próprio culto à afirmação ostensiva da personalidade, consiste no próprio gesto pelo qual os indivíduos se oferecem no mercado como mercadorias. Tal gesto deve ser compreendido como reação defensiva ao processo de despersonalização que atinge os indivíduos ao se tornarem fungíveis, mera engrenagem intercambiável e supérflua da maquinaria do sistema socioeconômico hodierno. Segundo a dialética adorniana, é buscando impor-se como diferentes que os indivíduos mais se identificam, reiterando a dissolução de sua individualidade na massificada sociedade de consumo. A este respeito, lemos no aforismo "Mônada", de Minima Moralia: "A situação em que o indivíduo desaparece é, concomitantemente, a de um individualismo desenfreado". ${ }^{22}$ Ou ainda, numa formulação análoga: "Quanto mais individualismo, tanto menos indivíduo". ${ }^{23}$ Compreendamos: quanto mais o sujeito se auto afirma, ostentando a máscara de sua persona, tanto menos indivíduo resta de fato sob a máscara.

Em suma, a afirmação ostensiva de uma personalidade artificial, enquanto reação defensiva às potências que compelem à dissolução da identidade, vigentes numa economia de mercado, reverte-se em mais despersonalização e só faz sancionar a despersonalização em curso. Como sentencia Adorno: "A situação atual é devastadora: para manter a identidade abstrata, da auto conservação pura e simples, é preciso perder a identidade". ${ }^{24}$ Daí a necessidade de, atendendo ao convite de uma

\footnotetext{
${ }^{21}$ Para a argumentação que desenvolvemos a seguir, baseamo-nos em duas secções subsequentes da Dialética Negativa, notadamente: "Contra o personalismo" e "Despersonalização e ontologia existencial”. Cf. AdORno, T. W. Dialéctica Negativa. Madri: Taurus, 1984, pp. 274-9.

${ }^{22}$ ADORno, T. W. Minima Moralia, op. cit., p. 131.

${ }^{23}$ Adorno, T. W. \& Horkheimer, M. Temas básicos de sociologia. São Paulo: Cultrix, 1973, p. 53. Citação ligeiramente modificada extraída da secção "Indivíduo" desta obra.

24 Adorno, T. W. Dialéctica Negativa, op. cit., p. 276. Interessante constatar o quanto o atual momento econômico comprova este diagnóstico adorniano da reversão dialética da afirmação da identidade aparente em perda de identidade. Com efeito, é inegável o caráter cada vez mais dissolvente que uma economia de mercado em constante transformação exerce sobre a conformação de identidades, sobretudo quando a inovação incessante desponta como pedra de toque de seu caráter concorrencial. A necessidade de assumir com prontidão os mais diversos papéis profissionais, estando disponível para assumi-los um após o outro, seguidamente, torna cada vez mais líquida a identidade do sujeito - para não dizer que é a liquidação de sua identidade que se consuma (a este respeito, é proveitoso ler Identidade, de Zygmunt Bauman).
} 
natureza difusa, acolher este impulso de despersonalização que levaria ao abandono de uma falsa identidade. Como escreve Adorno, numa passagem bastante citada da Dialética Negativa:

Humanos são os homens apenas quando não atuam como personagens [isto é, como atores sociais alienados] e não se põem absolutamente como tais; o difuso da natureza, [que se instaura] quando não são personagens, assemelhase ao delineamento e um ser inteligível, justamente aquele que estivesse redimido do eu; a arte contemporânea encontra-se inervada de algo disso. ${ }^{25}$

O apreço por este impulso de despersonalização, que aqui investigamos, poderíamos ainda contemplá-lo à luz da crítica endereçada por Adorno ao conceito kantiano de liberdade transcendental. Para Kant, com efeito, é a absoluta independência do agir moral relativamente à natureza externa, regida por determinismos causais inflexíveis, que se põe como determinante da personalidade humana. Numa passagem decisiva da Crítica da Razão Prática, lemos: "Nenhuma outra coisa é a personalidade senão isto, a liberdade e a independência relativamente ao mecanismo da natureza inteira, ao mesmo tempo que considerada, porém, como a faculdade de um ser que está puramente submetido às leis práticas ditadas pela sua própria razão". ${ }^{26}$ Ora, é precisamente visando quebrar a ilusão de soberania do sujeito, promovida por tal conceito de personalidade, que se orienta o pensamento adorniano. O sujeito deve ser capaz de renunciar a esta forma de personalidade entendida como virtude distintiva e baseada numa presumível soberania espiritual (que o exercício autônomo da razão Ihe garantiria), para acolher a natureza difusa que the é constitutiva - e que mesmo o determina à sua revelia. Em outras palavras, o sujeito deve ser capaz de se libertar da cela configurada pelo mito de sua autarquia individual em que tal conceito de personalidade o confina.

O desiderato adorniano seria, portanto, a renúncia a uma identidade consolidada (como unidade sintética enrijecida) em conformidade com o papel prescrito aos indivíduos numa sociedade capitalista de economia de mercado, marcada pelo individualismo, pela competição e pela frieza calculista. Renúncia esta

\footnotetext{
${ }^{25}$ Idem, p. 274.

${ }^{26}$ KANT, Immanuel. Crítica da Razão Prática. Lisboa: Edições 70, p. 156; tradução ligeiramente modificada.
} 
capaz de propiciar o surgimento de uma ipseidade liberada do interesse individual monadológico. Notemos que, nesse processo, Adorno busca salvar o sujeito emancipando-o de um pensamento fundado na identidade: a renúncia ao interesse individual monadológico franquearia a abertura à experiência da alteridade. Em contraposição ao desiderato de dessubjetivação (que aposta na liquidação do sujeito), a categoria do sujeito permaneceria salvaguardada, então, como lócus da não identidade. Seria esta despersonalização a condição de possibilidade para a emergência de uma autêntica individuação.

O reconhecimento, por parte do indivíduo, de que sua existência depende da existência de outros, e mesmo de um todo social do qual toma parte, delineia a experiência de sua heteronomia. Ora, uma etapa decisiva desta experiência se perfaz pelo penoso reconhecimento do quanto a liberdade individual, que tanto the apraz afirmar, se revela débil e ilusória quanto mais se exerce atrelada ao interesse individual monadológico e, portanto, alheia ao social.

Assim, é contra o personalismo individualista e ostentatório que Adorno advoga a despersonalização, mas não - é importante ressalvar - enquanto promotora da mera impessoalidade. Nesse sentido, Adorno se posiciona contra a despersonalização. Isso porque, na assimilação prazerosa da despersonalização, Adorno descobre o fascínio pelo processo em curso, nas sociedades hodiernas, de liquidação da individualidade, que passa a ser tomado como fatalidade inelutável: "Mas a sombria decisão de se despersonalizar curva-se ante uma fatalidade sentida como inelutável, em vez de acenar com a possibilidade de que a pessoa possa alcançar sua verdade." ${ }^{27} \mathrm{O}$ alvo dileto de sua crítica aqui é ontologia existencial heideggeriana que, segundo ele, assimila acriticamente o horror da despersonalização. Compreendido como ser para a morte, o Dasein heideggeriano manifesta esta inclinação sombria pela liquidação da individualidade. Compreendido abstratamente como pura possibilidade, este mesmo Dasein reafirma a impessoalidade imposta a cada indivíduo na realidade socioeconômica. Mas, ao lado de Heidegger, seria preciso ainda perfilar Stravinski como alvo dileto de Adorno na crítica endereçada ao feliz assentimento com a liquidação do eu. Se aquele constitui seu alvo dileto no domínio da filosofia, este último poderia figurar como seu alvo dileto no âmbito da teoria estética. Com efeito, as composições de Stravinski, segundo Adorno, fazem "o gesto de quem, privado do próprio sujeito, se entrega ao onipotente destino de morte do qual zombava momentos antes". ${ }^{28}$ A angústia que deveria provocar a desumanização transfigura-se, em suas ${ }^{27}$ AdORno, T. W. Dialéctica Negativa, op. cit., p. 277.

${ }^{28}$ Adorno, T. W. Filosofia da Nova Música. São Paulo: Perspectiva, 1989, p. 133. 
composições musicais, no prazer propiciado pelo impulso de morte. Com isso, o sacrifício do eu, exigido pelo atual momento histórico, nelas se apresenta como uma entrega sedutora. ${ }^{29}$

O ensaio "Stravinski e a restauração", que integra a Filosofia da Nova Música, contém algumas passagens de extrema relevância para compreensão daquilo que poderíamos chamar de má-despersonalização. Ali, a despersonalização é caracterizada como um comportamento regressivo e, segundo classificação da teoria psicanalítica, integrante do quadro clínico da esquizofrenia. Vista negativamente, a despersonalização caracteriza-se por um traço marcante: pela impassibilidade do sujeito, por sua indiferença (hebefrênica) com relação ao mundo. O sujeito despersonalizado não é capaz de se deixar tocar pelos objetos, o que impossibilita a expressão: "A expressão, que procede sempre da dor do sujeito frente ao objeto, está cortada, pois já não se chega a um contato". ${ }^{30}$ Na Filosofia da Nova Música, a crítica a Stravinski se estabelece em grande medida na contraposição com seu antípoda, Schoenberg. Neste, a categoria de sujeito se encontra salvaguardada, segundo Adorno, graças ao livre curso da expressão do sofrimento, que permite desencadear a autorreflexão por parte do sujeito. ${ }^{31}$

Neste ponto, poderíamos acrescentar que o que deve ser quebrado no sujeito despersonalizado (ou vitimado pela má-despersonalização) é justamente aquilo que tornou Auschwitz possível, "a frieza das mônadas sociais, do competidor isolado, enquanto indiferente ao destino dos demais". ${ }^{32}$ Em contrapartida, o sujeito que logra alcançar uma verdadeira personalização mostra-se capaz de, pelo esquecimento de si mesmo, fazer a experiência do outro, o que significa: renunciando a sua estrita visada subjetiva, deixar-se tocar pelo outro, tornando-se capaz de se angustiar com o sofrimento alheio, pois a angústia não deve ser reprimida: "é preciso sentir tanta angústia quanto esta realidade merece, só assim poderá desaparecer em grande medida o efeito destrutivo da angústia inconsciente e desviada". ${ }^{33}$ Assim também, na

\footnotetext{
${ }^{29}$ Nesta caracterização negativa da despersonalização, é interessante sublinhar a presença de elementos que fazem lembrar um dos traços característicos de Walter Benjamin salientados por Adorno, a que já nos referimos, qual seja, seu traço de esquizofrenia, de alguém alheado da própria physis, “de alguém que dava a impressão de não ter corpo”. Vale ainda relembrar que Adorno inquietava-se ao pressentir no amigo dileto a mesma inclinação pela impessoalidade, ainda que de forma mais nuançada. Sua preocupação era a de que a anulação da subjetividade que diagnosticava em Benjamin, seu antisubjetivismo, como o designava, comprometesse a necessária força de resistência crítica do indivíduo.

30 Cf. Adorno, T. W. Filosofia da Nova Música, op. cit., p. 136.

${ }^{31}$ Ver, a respeito, WAIzBorT, Leopold. "Sacrifício e liquidação do sujeito: Notas sobre a sociologia da música em Adorno”. Revista Tempo Social, 2 (2), 1990, p. 157.

32 Adorno, T. W. Palavras e Sinais. Petrópolis: Vozes, 1995, p. 120. Do ensaio "Educação após Auschwitz".

${ }^{33}$ Idem, p. 114-5; Adorno, T. W. Consignas. Buenos Aires: Amorrortu, 1973, p. 88.
} 
conferência Glosa sobre personalidade, Adorno descreve nos seguintes termos a formação da personalidade do indivíduo em sua forma justa: "o sujeito deve chegar a si mesmo não mediante o culto narcisista de si, mas sim mediante o alheamento de si [Entäusserung], à renúncia de si e à dedicação ao outro". ${ }^{34}$

Esse processo acalentado por Adorno consumar-se-ia, portanto, mediante o abandono de uma coação sistemática imposta pelo princípio de auto conservação individualista reinante nas sociedades capitalistas hodiernas, que permitiria ao indivíduo entregar-se mais espontaneamente à sua própria consciência e experiência. Tal abandono de uma identidade empedernida (de uma falsa personalidade) facultaria ao sujeito a real experiência de cada objeto, que é uma experiência fundamentalmente qualitativa, liberada da tendência quantificante imposta pela objetivação cientificista (nesse sentido, tal abandono vai de par com o abandono da coação identitária promovida pela racionalidade instrumental e, no mesmo movimento, com a reapreciação da componente mimética do pensamento). Ou melhor, facultaria ao sujeito a realização da experiência que se encontra interditada ao indivíduo submetido à alienação vigente nas sociedades capitalistas - e que é a única experiência verdadeira: a experiência da alteridade. Esta experiência demanda, fundamentalmente, deixar-se tocar pelo sofrimento alheio, com o que despertam os sentimentos de solidariedade e de cooperação, os quais conduzem ao reconhecimento do interesse comum. Assim como o particular só é capaz de se definir claramente no estabelecimento de sua relação com o universal, a despersonalização almejada por Adorno poderia, portanto, ser compreendida nos seguintes termos: como a emergência de uma verdadeira individuação, só possível de ser alcançada mediante um processo de diferenciação capaz de contemplar a singularidade inalienável de cada indivíduo na sua relação com o universo social. Processo este que faria despertar um sujeito crítico e solidário, cuja experiência se abre para a participação coletiva e histórica.

Nós, porém, integrantes de um sistema socioeconômico que alimenta o mito da liberdade e autossuficiência individual, já não existimos há muito como indivíduos, mas como meros objetos, coisas mortas. Lemos no aforismo "Palhaço", de Minima Moralia:

\footnotetext{
${ }^{34}$ Idem, p. 67; Idem, p. 52.
} 
A desgraça não ocorre como uma eliminação radical do que existiu [o indivíduo], mas na medida em que o que está historicamente condenado [o indivíduo] é arrastado como algo de morto, neutralizado, impotente, e se vê afundando de maneira ignominiosa. Em meio às unidades humanas padronizadas e administradas, o indivíduo vai perdurando". ${ }^{35}$

A angustiante tomada de consciência desta situação, o doloroso reconhecimento da despersonalização que vitima cada um de nós, hodiernamente, configura uma etapa decisiva e essencial deste processo, acalentado por Adorno, rumo à consolidação de uma autêntica personalidade. Como afirma Adorno reiteradamente, o sujeito precisa se libertar do mito de sua liberdade e autossuficiência - esta é a condição prévia e indispensável para conquista de uma autêntica autonomia, ou de uma autêntica personalidade. Destarte, a única imagem ainda possível do indivíduo, ainda que efêmera e condenada, é aquela que apresenta a dissolução desse indivíduo e, ao mesmo tempo, o horror dessa dissolução. Ora, essa imagem angustiante e liberadora a um só tempo não seria aquela que uma experiência estética específica nos permitiria contemplar? Experiência esta que facultaria ao sujeito fruir de sua própria morte, na exata medida em que este se reconhece em objetos insignificantes, arruinados e desprezíveis, os quais refletem a liquidação de sua individualidade como sua verdadeira imagem.

Com efeito, o impulso de perda de identidade almejado por Adorno (como sendo aquele que conduz a uma autêntica individuação) é propiciado, em grande medida, por uma experiência estética definida, identificada na arte de vanguarda de seu tempo. É o que procuraremos expor nas páginas seguintes, ao tratar do conceito adorniano de mímesis. Associado à manifestação de uma pulsão de morte no sujeito, o motivo da despersonalização, aqui apresentado, concorre para dotar o conceito adorniano de mímesis de uma ambivalência específica, como faremos ver.

\section{Ambivalência da mímesis em Adorno}

Comecemos por observar que, em nome da expressão do sofrimento que pesa objetivamente sobre o sujeito, graças à qual ele lograria empreender o doloroso reconhecimento da despersonalização que o vitima, a obra adorniana no seu todo elabora duas recomendações à primeira vista distintas:

\footnotetext{
${ }^{35}$ Adorno, T. W. Minima Moralia, op. cit., p. 118.
} 
i) No âmbito de atividade do pensamento conceitual, que se volta criticamente para a objetividade da racionalidade positivista, com sua correspondente propensão por fazer abstração da singularidade concreta, Adorno propõe uma espécie de reflexão mimética, capaz de reincorporar a materialidade corpórea renegada, com a correspondente reapreciação do momento de expressão subjetiva (este é o teor dominante da proposta presente na Dialética Negativa);

ii) No âmbito de exercício da experiência estética, que se inclina para a exacerbação dos aspectos subjetivos associados à expressão, Adorno realiza uma crítica da expressão para assegurar a primazia do objeto, propondo uma espécie de mímesis reflexiva (esta é a proposta delineada notadamente na Teoria Estética).

Em razão dessa flutuação dialética que tem lugar entre o domínio da atividade conceitual e o da experiência estética, podemos discernir duas noções aparentemente distintas do processo mimético presentes na obra adorniana. No plano da atividade conceitual, a mímesis requerida é fundamentalmente mímesis do corpo vivo, isto é, um processo de reapreciação e incorporação, por parte do sujeito, da materialidade corpórea renegada; processo este que atende ao apelo do contato caloroso e do colorido vital, em vista da conquista de uma autêntica individuação (onde há impessoalidade em demasia, um convite à personalização). Já no plano da experiência artística autêntica, a mímesis indicada é sobretudo mímesis do corpo morto, isto é, um processo de distanciamento do colorido vital mediante a reapreciação das pulsões que convidam à dissolução de uma falsa identidade (onde há individualismo exacerbado, um apelo à despersonalização).

Estas duas noções de mímesis assim apresentadas (do corpo vivo e do corpo morto) remeteriam, de fato, a duas concepções distintas do processo mimético? Ou representariam elas dois aspectos complementares de um mesmo processo mimético? Procuraremos aqui argumentar em favor desta segunda hipótese, como se verá, acusando a existência de uma imbricação profunda entre reflexão mimética e mímesis reflexiva.

Buscando compreender como se articulam essas duas noções de mímesis (mímesis do corpo vivo e mímesis do corpo morto) no pensamento adorniano, seria proveitoso recorrer aqui ao belo estudo de Vladimir Safatle sobre a dialética adorniana, A Paixão do Negativo. A leitura deste estudo nos permite compreender que a ambivalência adorniana em relação à mimese decorre da articulação entre dois motivos centrais de sua dialética, quais sejam:

i) o primado do objeto; 
ii) o descentramento do sujeito (este, associado ao motivo da despersonalização).

O motivo do primado do objeto, que propugna uma abertura às coisas sem conceito mediante a reapreciação mimética da materialidade corpórea e opaca, conjuga-se com o motivo da despersonalização, que defende a libertação do sujeito de uma identidade empedernida - falsa individualidade consolidada em conformidade com uma estrutura social marcada pelo individualismo, pela competição e pela frieza calculista (ou pelo primado da auto conservação individual), como salientamos há pouco. Ora, notemos que é precisamente esta articulação que esclarece, em grande medida, a paradoxal caracterização de Benjamin feita por Adorno a que nos referimos na abertura deste trabalho.

Lembremos inicialmente que o primado do objeto não deve ser entendido como hipóstase do não conceitual, positividade ontológica no limite inacessível ao conceito, mas sim como figura de negação da identificação imposta ao objeto pelo conceito, a acusar a resistência do objeto à sua instrumentalização pelo pensamento identificador. Destarte, o motivo do primado do objeto delineia um conceito negativo de natureza: a natureza se manifesta como aquilo que resiste ao regime de apropriação identitária do sujeito. Conceito negativo que busca, mediante a incorporação do momento mimético, fazer-se sensível ao não conceitual, vale dizer, àquilo que nas coisas anseia por uma expressão não contemplada pelo conceito. Mas essa abertura às coisas opacas e insignificantes desprezadas pelo conceito só pode se perfazer quando o sujeito logra se liberar do regime de apropriação identitária imposto aos objetos. Tal suspensão do regime simbólico de produção de identidade exige, por sua vez, que o próprio sujeito abandone uma identidade cristalizada no interior de um universo simbólico estruturado - ou, nas palavras de Adorno, que o sujeito morra como pessoa.

O motivo da despersonalização desloca o foco da atenção do objeto para o sujeito. O primado do objeto requer o descentramento do sujeito. Tal motivo coloca em cena a noção de pulsão de morte: é graças a ela que o sujeito pode gozar de sua morte como pessoa porquanto se satisfaz com o caráter eminentemente negativo dos objetos (objetos insignificantes, arruinados, desprezíveis). Ao fazer a experiência de certos objetos singulares que contradizem sua própria identidade - como é o caso dos objetos estéticos da arte de vanguarda apreciados por Adorno - o sujeito pode gozar de sua perda de identidade. Procurando explicar melhor, poderíamos dizer que o objeto da pulsão é um objeto eminentemente negativo que traz em si sua própria negação, por meio do qual o sujeito não mais reconhece a imagem identitária que 
fazia de si mesmo. Ora, justamente desse modo poderíamos caracterizar os objetos da arte autêntica, como "objetos que suportam em si uma contradição que impede o estabelecimento da auto identidade" ${ }^{36}$, ou como objetos que representam uma torção de seus protocolos de identidade, nas palavras de Safatle. Daí a aproximação maior existente entre Adorno e Lacan evidenciada magistralmente por Safatle:

Assim, para os dois, que não querem simplesmente eliminar a categoria de sujeito, mas livrá-lo do pensamento da identidade, só há cura possível através do acesso a uma experiência de descentramento e de não-identidade cujo modelo é fornecido preferencialmente pela força disruptiva da arte contemporânea. Uma experiência que permite a Lacan encontrar um modo de objetivação da emergência da pulsão como negação que impõe limites à identidade de um pensamento conceitual resvalado à condição instrumental ${ }^{37}$.

Embora a experiência estética não seja a única experiência de descentramento possível facultada ao sujeito, não se pode negar que ela constitui, para Adorno, seu modelo privilegiado. É correto afirmar, por isso, que o descentramento do sujeito tem oportunidade de se consumar graças principalmente à experiência estética proporcionada pela arte autêntica. Mas se a arte contemporânea autêntica possui, de fato, uma potência disruptiva, essa potência extrai sua força da pulsão de morte que habita o sujeito, isto é, da tendência pulsional a regressar a um estado de natureza marcado pela despersonalização.

Assim, é graças à atuação da pulsão de morte que o sujeito pode sentir-se impelido a abandonar a máscara de sua pessoa. Em contrapartida, dado seu apego à identidade estabelecida, a destruição da imagem que acalenta de si mesmo se lhe afigura temerária, fazendo-o resistir a abandonar a máscara de sua pessoa: "A individuação tornou-se tão difícil para os homens, e é ainda tão incerta, que eles são tomados por um susto mortal assim que se levanta um pouco o seu véu". ${ }^{38}$ Pois, uma vez soerguido o véu, podem vislumbrar que não são eles mesmos, são meras coisas mortas, poderíamos prosseguir. Justamente por isso, a verdadeira obra de arte é

${ }^{36}$ Safatle, Vladimir. A Paixão do Negativo: Lacan e a dialética. São Paulo: Editora Unesp, 2005, p. 286.

${ }^{37}$ Idem, p. 279. Não nos deteremos aqui sobre as ricas e fecundas correspondência existentes entre o pensamento lacaniano e o adorniano. Ao leitor interessado, indicamos a obra já mencionada de Vladmir Safatle, A Paixão do Negativo: Lacan e a dialética. Relativamente ao tema em questão, são especialmente valiosas as seguintes passagens desta obra: "A morte como pulsão" (pp. 275-9); "Mimese, natureza e estranhamento", (p. 309); "Deslocamento no interior da aparência" (p. 295); "Schönberg mimético" (p. 311).

${ }^{38}$ ADORno, T. W. Prismas, op. cit., p. 249. Do ensaio “Anotações sobre Kafka”. 
aquela que nos endereça um convite, ardiloso e sedutor ao mesmo tempo, capaz de vencer esta resistência e proporcionar uma experiência singularíssima, em que a pulsão de morte logra vir à tona, promovendo uma dissolução da identidade que não deixa de ser prazerosa. Fruímos, então, de nossa própria morte e o calafrio que acompanha esta fruição é, segundo Adorno, o sinal característico da autêntica experiência estética.

Há um intrigante aforismo de Minima Moralia, "Regressões", em que Adorno comenta as impressões prazenteiras que, desde criança, Ihe causavam a canção "Entre a montanha e o vale profundo" e cuja interpretação poderia ser feita a partir do motivo que desenvolvemos aqui, o da experiência da morte em vida ${ }^{39}$. Nesta canção, um caçador atinge duas lebres ferindo-as de morte, mas de uma morte que curiosamente desperta para a vida. A ambiguidade que esta morte carrega é, sem dúvida, desconcertante e causa espécie desde a primeira leitura. Escreve Adorno neste aforismo:

Desde que sou capaz de pensar, que me faz feliz a canção 'Entre a montanha e o vale profundo': a história de duas lebres que se empanturraram de grama, foram abatidas pelo caçador, e, ao constatarem que ainda estavam vivas, saíram correndo.[...] Deve-se fazer como as duas lebres; quando o tiro vem, cair fingindo de morto, juntar todas as suas forças e refletir, e, se ainda tiver fôlego, dar o fora. ${ }^{40}$

Ora, não seria despropositado, a nosso ver, identificar esse tiro mortal com a despersonalização apreciada por Adorno, aquela deflagrada preferencialmente, mas não só, por uma autêntica experiência estética - aquela que convida à morte da persona forjada e cristalizada pelo princípio de auto conservação individualista, prevalecente no sistema socioeconômico capitalista. Despersonalização que é tanto angustiante tomada de consciência de sua morte em vida (o horror da constatação do caráter fantasmático de sua autonomia individual) como, ao mesmo tempo, alegre despertar para a vida de uma autêntica individuação. Pois o que Adorno almeja para o

\footnotetext{
39 Para uma exposição mais detalhada deste importante motivo de pensamento em Adorno, recomendamos ao leitor notadamente a terceira parte do livro: CHIARELLO, M. Natureza-morta: Finitude e negatividade em T.W. Adorno. São Paulo: Edusp, 2006 (pp. 221-266). Sobre o papel decisivo que nele desempenha a experiência estética, ver, em especial, a seç̧ão "A morte através das obras" (p.257).

${ }^{40}$ ADORNo, T. W. Minima Moralia. op. cit., p. 175.
} 
indivíduo é esta forma de experiência de abertura ilimitada, que chega ao ponto de renunciar a si mesmo, e na qual o que sucumbe se reencontra. A este respeito, sentencia Adorno em outro aforismo de Minima Moralia: "só quem perder sua vida há de salvá-la". ${ }^{41}$

Retornemos à aludida ambivalência adorniana em relação à mímesis. Como se compreende, o momento mimético de reconciliação com o objeto, proporcionado por um pensamento capaz de incorporar as categorias de semelhança e analogia, de simpatia e participação (censuradas pelo racionalismo moderno como próprias de um pensamento mágico), conjuga-se com o momento mimético de dissolução do eu enquanto identidade empedernida, ou melhor, destruição de uma identidade consolidada no interior de um universo socioeconômico estruturado pela categoria predominante da auto conservação individual - que Adorno denomina amiúde como sendo o universo da total administração.

Se o objeto mimético é objeto que promete reconciliação ele é igualmente objeto que promove a perda da identidade do sujeito; diante dele, o sujeito se vê diante de um sensível que é "materialidade sem imagem", que o convida ao descentramento, a não mais se reconhecer na imagem que fazia de si mesmo. Assim, o impulso mimético de perder-se na identificação com um outro carrega em si essa ambivalência: a reconciliação redentora com o objeto conjuga-se com a negação da identidade empedernida do sujeito. No artigo "Espelho sem imagens", Vladimir Safatle procura justamente explicar a ambivalência de que se reveste o conceito de mímesis em Adorno pelo caráter solidário entre reconciliação e destruição que tem lugar no processo mimético. Isto é, entre o impulso de reconciliação com o objeto e o impulso de despersonalização entendido, nas suas palavras, como processo de "destruição do eu como identidade estática no interior de um universo simbólico estruturado." ${ }^{42}$

A reapreciação da potência cognitiva que possui a mímesis (potência esta denegada pelo pensamento esclarecido, vale dizer, pela racionalidade científica moderna) exige, portanto, considerar um sujeito cuja identidade pode sim perder-se na identificação com um outro, abandonando a possessão de si como máscara impenetrável ${ }^{43}$. Ora, não é precisamente este o movimento de duplo sentido que Adorno reconhece como sendo um dos traços mais característicos de Benjamin?

\footnotetext{
${ }^{41}$ Idem, p. 132. Do aforismo "Mônada".

42 SAfatLe, Vladimir. "Espelhos sem imagens: Mímesis e reconhecimento em Lacan e Adorno", Trans/Form/Ação, 28(2), 2005, p. 38.

${ }^{43}$ Ver o artigo, já mencionado, "Espelhos sem imagens".
} 
Notadamente quando o descreve como alguém que dava a impressão de não ser uma pessoa, no sentido existencial do termo (ou de ser alguém morto como pessoa), cujo olhar infinitamente triste contemplava o mundo do ponto de vista dos mortos, mas que, ao mesmo tempo, era capaz de acolher calorosamente toda vida enregelada, sem jamais se esgotar?

Para Adorno, uma das maiores virtudes da experiência estética - se não a maior delas - consiste justamente na promoção do descentramento do sujeito. De fundamental importância, nesta experiência, é o momento de desvanecimento do eu, que se faz acompanhado de um estremecimento ou comoção profunda. Graças a ele, o sujeito logra se libertar de sua estreita visada subjetiva, acedendo a um outro ponto de vista sobre o mundo, mais legítimo que aquele em que se aferrava cegamente. $O$ processo que então se consuma apresenta, por isso, os elementos de uma anagnórise, pelo qual o sujeito vem a se dar conta da cegueira obstinada que manteve para com a manifestação de subjetividades alheias, passando a reconhecer a existência e a legitimidade de outros anseios, que não exclusivamente os seus, perante os quais se manteve impassível. Como resultado desta experiência de alteridade e transcendência, o sujeito termina por formar uma ideia mais justa de si mesmo e da realidade que o cerca.

Atentos à relevância deste momento, durante o qual a soberba subjetiva se vê profundamente abalada perante uma dimensão objetiva que se Ihe afigura abismal ou terrífica, a ponto de revelar ao sujeito sua finitude e insignificância - quando não sua falta, ou mesmo sua culpa -, um bom número de comentadores observa que, na obra adorniana, a autêntica experiência estética apresenta os traços característicos do sublime artístico. É o caso, por exemplo, de Wolfgang Welsch, que considera a teoria estética adorniana como sendo uma estética implícita do sublime: "Tanto por sua índole como por suas diretrizes principais, a estética de Adorno se apresenta como uma estética do sublime". ${ }^{44}$ Esta apreciação nos parece muito justa, sobretudo quando

\footnotetext{
44 WELSCH, Wolfgang. “Adornos Ästhetik: eine implizite Ästhetik des Erhabenen” apud FREITAS, Verlaine. "A arte moderna como historicamente-sublime: Um comentário sobre o conceito de sublime da Teoria Estética de T.W. Adorno”, Kriterion, no. 127, jun/2013, p. 163. Sobre a presença de elementos característicos do sublime artístico na teoria estética adorniana, recomendamos ao leitor o artigo de Verlaine Freitas que acabamos de mencionar, e do qual extraímos esta citação. Vale observar ainda que, de uma perspectiva histórica, a emergência da estética do sublime introduz uma ruptura na estética clássica fundada na noção de mímesis enquanto adequação entre sujeito e objeto, considerada condição de possibilidade da representação figurativa. Como se compreende, portanto, a estética adorniana opera com uma nova forma de mímesis associada ao sublime - e está muito longe de defender a mímesis como adequação imediata e espontânea entre sujeito e objeto.
} 
consideramos que o sublime pode ser visto como índice da inadequação essencial entre sujeito e objeto. Enquanto sublime, o objeto se apresenta em sua singularidade irredutível, absolutamente refratário às faculdades de representação do sujeito, mostrando-se por isso disforme e monstruoso. O objeto se impõe, então, ao sujeito em sua alteridade radical, que escapa às suas potências de representação.

A este respeito, poderíamos lembrar que o index veri da autêntica experiência estética é, para Adorno, o calafrio ou a comoção profunda que a acompanha: o abalo [Erschutterung], justamente graças ao qual o sujeito logra olhar para fora da prisão de seu próprio eu. Numa conhecida passagem de sua Teoria Estética, é com as seguintes palavras que Adorno descreve esta experiência:

A comoção profunda [Erschutterung], brutalmente contraposta ao conceito usual de vivência, não é uma satisfação particular do eu, e é diferente do prazer. É antes um momento de liquidação do eu que, enquanto abalado, percebe os próprios limites e finitude. Essa experiência é contrária ao enfraquecimento do eu, que a indústria cultural promove. [...] A fim de olhar apenas um pouquinho para além da prisão, que ele próprio constitui, o eu precisa não da dispersão, mas da mais extrema tensão; isso preserva o abalo profundo, de resto um comportamento involuntário, da regressão. ${ }^{45}$

Uma leitura atenta desta tão citada passagem permite, no entanto, perceber uma preocupação mal dissimulada - e é este o motivo pelo qual quisemos mencionála aqui por inteiro. Notemos que Adorno faz questão de ressaltar que o momento de liquidação do eu, provocado pela comoção estética, constitui uma "experiência contrária ao enfraquecimento do eu". Quando o faz, pressentimos, nas entrelinhas, a necessidade de afugentar um fantasma, qual seja: o receio de que este "momento de liquidação do eu" possa, sim, encontrar-se vinculado ao enfraquecimento do eu - e venha redundar, caso hipostasiado, na má-despersonalização do sujeito, justamente caracterizada como um comportamento regressivo promovido pela indústria cultural (referimo-nos aqui a esta crítica na interpretação das obras de Stravinski). Tal pressentimento se vê confirmado pela sentença final do parágrafo, que acrescenta ser este abalo profundo, afinal, "um comportamento involuntário e regressivo".

Isto para evidenciar, mais uma vez, a renitente ambivalência de Adorno relativamente ao motivo da perda de identidade do sujeito. Afinal, o momento de

\footnotetext{
45 AdoRno, T. W. Teoria Estética. São Paulo: Martins Fontes/Edições 70, 1988, p. 274 (tradução ligeiramente modificada).
} 
dissolução do eu vê-se indiscutivelmente valorizado na estética adorniana, mas apenas conquanto não termine por acarretar um sujeito despersonalizado, propenso a se identificar acriticamente com o existente. Não devemos jamais perder de vista a finalidade última que este momento apresenta para Adorno, qual seja: que o sujeito logre alcançar um grau de consciência mais amplo e crítico - e que assim fortaleça sua identidade enquanto capacidade de resistência às tendências imperantes de liquidação do indivíduo. Se é certo que este momento concorre para a emancipação de uma subjetividade impassível cegamente voltada sobre si mesma, propiciando uma experiência de abertura ao outro, quer natural, quer social, não é menos certo, convém sublinhar, que este mesmo momento não encerra qualquer apelo para que o sujeito renuncie à lucidez analítica de sua razão e à atenção aguda de sua consciência, somente graças às quais pode se constituir como indivíduo dotado de força de resistência crítica.

Embora venha a exigir um momento de despersonalização, o sentido último deste processo que leva à boa personalização é, portanto, aquele que aponta para o do fortalecimento do eu - ao qual, justamente, alude o antigo ideal de personalidade, hoje obsoleto. Devemos ter isto em mente para bem entender o desiderato de que o sujeito deixe de ostentar sua personalidade, ou de se exibir como personalidade. Quando Adorno enseja que o sujeito deixe de ser uma personalidade (cultivada como fetiche ou valorizada com mercadoria), para ter de fato uma personalidade, ter significaria aqui possuir uma individualidade efetivamente dotada de autonomia e força de resistência crítica. E, para Adorno, a força do eu é, em última instância, dependente da consciência e da racionalidade, às quais compete o exame crítico da realidade. ${ }^{46}$ Notemos que, neste ponto, Adorno reconhece o momento de verdade do conceito kantiano de personalidade (ao qual nos referimos anteriormente de forma crítica) e lamenta, consequentemente, a liquidação hodierna do momento de autonomia, liberdade e resistência do indivíduo, que ainda ressoava no antiquado ideal de personalidade: "O conceito de personalidade é irrecuperável. No entanto, no momento histórico de sua liquidação, algo dele deveria ser conservado: a força do indivíduo, o poder de que este necessita para desconfiar e não se identificar cegamente com aquilo que se lhe impõe". 47

\footnotetext{
46 No aforismo "Regressões", a que nos referimos há pouco, vale ler com atenção o que Adorno recomenda àquele que se percebe liquidado enquanto indivíduo: "quando o tiro vem, cair fingindo de morto, juntar todas as suas forças e refletir" (o grifo é nosso).

47 Adorno, T. W. Palavras e Sinais, op. cit., p. 68; Adorno, T. W. Consignas, op. cit., p.52. Da conferência "Glosa sobre personalidade".
} 


\section{Entre a dissolução e o fortalecimento do eu na práxis coletiva}

À guisa de conclusão, gostaríamos de contemplar, ainda que brevemente, as teorias estéticas formuladas por Adorno e Benjamin sob um aspecto específico, qual seja, a partir da relação que estas teorias intentam estabelecer com a práxis histórica. $\mathrm{Na}$ divergência que as respectivas teorias revelam sob este aspecto, insinua-se, como veremos, a mesma ambivalência mantida por Adorno para com o momento perda de identidade do sujeito. Além disso, a comparação destas teorias, feita à luz da relação mantida com a práxis histórica, propicia uma visão mais abrangente do contexto em que se insere este motivo de pensamento que aqui investigamos.

Em uma passagem de Educação após Auschwitz, Adorno julga preciso ressalvar, para não ser mal-entendido, que não prega o amor quando afirma a necessidade de superação da impassibilidade das mônadas sociais frente a destino dos demais. Não que o sentimento de amor para com o próximo the pareça demeritório ou mesmo censurável, muito pelo contrário, mas sim porque se mostra insuficiente de modo cabal. Adorno tem clara consciência (e consciência crítica) de que esta superação não depende exclusivamente do indivíduo isolado, posto que requer a transformação da ordem social vigente - ordem esta que, forjando identidades norteadas pelo interesse individual monadológico, promove reiteradamente a indiferença reinante entre os competidores isolados: "Um dos grandes impulsos do cristianismo [...] foi o de extinguir a frieza que penetra a tudo. Mas esta tentativa fracassou, precisamente porque deixou intacta a ordem social que produz e reproduz a frieza". ${ }^{48}$

Assim, com implacável lucidez, Adorno insistiu na necessidade inescapável de transformação da dimensão social e política. Ao mesmo tempo, porém, julgou que as possibilidades de intervenção direta sobre esta dimensão objetiva e mais essencial escapava então a nosso raio de ação (estamos aqui nos referindo ao último Adorno, autor da Teoria Estética). Mais ainda, a possibilidade de alteração da ordem social ou política, via atuação prática direta sobre elas, pareceu-lhe de eficácia limitada e mesmo duvidosa. Especialmente em sua obra tardia, defendeu por isso a necessidade de desviar os esforços para a dimensão subjetiva, o que foi por ele designado como um "giro para o sujeito".

Em consonância com este giro propugnado, devemos reconhecer que o enfoque de sua teoria estética recai notadamente sobre a subjetividade do indivíduo

${ }_{48}$ Adorno, T. W. Palavras e Sinais, op. cit., p. 120; Adorno, T. W. Consignas, op. cit., p.93. Da conferência "Educação após Auschwitz". 
isolado. Para Adorno, o efeito liberador propiciado pela autêntica experiência estética auferida pela arte de vanguarda de seu tempo (fruída por muito poucos, seja dito de passagem) consiste fundamentalmente, como já assinalamos aqui, na quebra do sortilégio que torna o sujeito isolado prisioneiro do interesse individual monadológico e, portanto, cegamente voltado para sua auto conservação. A função da arte - se podemos dizer que a arte possui uma função - seria a de fazer reluzir a promessa de felicidade de uma sociedade emancipada, na qual deixasse de parecer temerária (passando a ser convidativa e prazenteira), aos olhos do indivíduo cegamente voltado para si mesmo, a entrega do eu a uma totalidade reconciliada.

Esta interpretação, que acusa o efeito emancipador sobre a subjetividade como sendo o enfoque determinante da teoria estética adorniana, não se vê invalidada pelo entrelaçamento ineludível entre o caráter sublime das obras e o seu teor de verdade necessariamente histórico. Ela permanece válida mesmo quando reconhecemos que a experiência de alteridade e transcendência, propiciada pelo caráter sublime da obra, possibilita, na estética de Adorno, a apreensão do teor de verdade das obras, que é histórico no sentido mais profundo do termo. Isto é, quando assentimos que a dissolução do eu possui, "como um de seus momentos, uma determinada forma de consciência do processo histórico"49.

Com efeito, a arte autêntica é vista, por Adorno, como uma passagem à espera de ser franqueada: à espera de que, um dia ainda, aquilo que encontrou ocasião de ser experimentado na clausura da obra, como imagem da clausura do eu, venha a se abrir efetivamente para uma outra forma de experiência histórica, que não a do universal administrado, rompendo a clausura do individual em prol do solidário acolhimento do outro. Em duas palavras: repercutindo no âmbito do coletivo, ainda que de forma indireta e imponderável, no sentido de uma real transformação das condições materiais da existência - em prol de uma existência reconciliada, fundamentalmente pautada pela colaboração, pela solidariedade e pela compreensão mútua. Transformação esta capaz de contemplar a promessa de felicidade que, na arte, resplandece com a doída tristeza do que não passa de mera aparência.

\footnotetext{
${ }^{49}$ FrEITAS, Verlaine. “Alteridade e transcendência: A dialética da arte moderna em Theodor Adorno”. In DuARTE, Rodrigo; FigueIRedo, Virgínia; KAngussu, Imaculada. Theoria Aesthetica: Em comemoração ao centenário de Theodor W. Adorno. Porto Alegre: Escritos, 2005, p. 5. A tese da íntima vinculação entre o conceito de sublime adorniano e o caráter histórico da obra de arte é sustentada por Verlaine Freitas, que destaca o fato de a teoria estética adorniana valorizar notadamente o sublime artístico e não exclusivamente o sublime natural, como ocorre em Kant. Esta tese é defendida mais extensa e detalhadamente no artigo "A arte moderna como historicamente-sublime: Um comentário sobre o conceito de sublime da Teoria Estética de T.W. Adorno”.
} 
Assim, ainda que Adorno não tenha jamais perdido de vista a necessária transformação das condições objetivas, o âmbito de influência imediata da arte permanece, em sua estética, restrito à clausura do eu. Que a arte pudesse repercutir diretamente sobre a práxis social de forma mais ampla e emancipadora; que uma arte de massas pudesse apresentar certo potencial transformador da ordem social, isto Adorno não pôde conceber. Identificada à indústria cultural e associada ao entretenimento diversionista, a arte de massas esteve destinada, para ele, a promover a debilidade de um eu em fase terminal, já propenso à identificação irrefletida e acrítica com a ordem existente. Em suma, a promover o conformismo, ao contrário da desejável resistência crítica.

Ora, esta não foi a posição assumida pelos últimos escritos de Benjamin. Instigante, a este respeito, a hipótese de leitura formulada no ensaio de Jeanne Marie Gegnebin, "Atenção e dispersão", sobre as distintas perspectivas assumidas pelas teorias estéticas de Adorno e Benjamin. Segundo esta hipótese, a teoria estética elaborada por Adorno assume fundamentalmente o ponto de vista do indivíduo solitário, mais exatamente do sujeito burguês das classes dominantes. Sua ênfase recai, assim, sobre o sujeito cujo processo de individuação viu-se pautado pelo princípio de auto- conservação, prevalecente num sistema socioeconômico em que contenção e repressão instintual forjaram a prisão de sua individualidade. A repressão que vitima estes sujeitos, para os quais o trabalho constitui uma servidão mais voluntária que impositiva, é antes interior que exterior. A teoria estética de Benjamin, em contrapartida, teria feito uma aposta mais ousada, aventurando-se a assumir a perspectiva dos sujeitos das classes oprimidas, para os quais a repressão é antes exterior do que interior, decorrente da escassez material e da necessidade do trabalho. Benjamin teria por isso confiado mais irrestritamente (e bem mais que Adorno pôde confiar) no potencial emancipador do impulso mimético liberado pelas novas formas de manifestações artísticas de seu tempo associadas ao desenvolvimento da técnica, como abertura de um espaço de jogo coletivo no cotidiano repetitivo e massacrante do trabalho. ${ }^{50} \mathrm{O}$ avanço tecnológico que tornou possível o desenvolvimento destas novas formas de arte, como a fotografia e o cinema, tornou ao mesmo tempo possível que estas formas de arte chegassem às massas. Por certo, a aposta benjaminiana no poder transfigurador da arte e na possível criação de novas formas de vida coletiva via práxis revolucionária, ainda que

\footnotetext{
50 Ver Gagnebin, Jeanne Marie. “Atenção e dispersão: elementos para uma discussão sobre arte contemporânea a partir de Adorno e Benjamin”. In Limiar, aura e rememoração: Ensaios sobre Walter Benjamin, São Paulo: Editora 34, 2014, pp. 112-4.
} 
violenta, não obteve a mesma aceitação por parte do último Adorno, que viu com grande desconfiança a militância política de seu tempo, terminando por se indispor com o ativismo estudantil de 1968 ao final de sua vida.

Corrobora esta diferença de perspectiva o registro feito por Rolf Wiggershaus em sua monumental história da Escola de Frankfurt. Observa ele que, a partir de 1967, Adorno passou a ser criticado pela publicação das obras de Benjamin realizada, nos anos 1950, sob sua coordenação. A acusação que se lhe dirige então é a de ter escamoteado, na seleção destas publicações, o Benjamin materialista e defensor do papel decisivo que teria a arte na luta de classes $^{51}$. Tais acusações sempre pareceram descabidas a Adorno, que nunca foi capaz de reconhecer como legítima esta vertente da obra benjaminiana, tomada por ele como um desvirtuamento dos propósitos originais de Benjamin, provocado, sobretudo, pela influência do marxismo militante advogado por Brecht, de quem Benjamin se aproximou nos últimos anos.

Assim, embora inegavelmente Adorno deva muitíssimo a Benjamin na formulação germinal de sua teoria estética, embora vários motivos da estética benjaminiana possam ser encontrados na Teoria Estética ${ }^{52}$, obra em que trabalhou durante os últimos anos de sua vida, é forçoso reconhecer que neste aspecto particular, relativo à sua interação com a práxis, as teorias estéticas desenvolvidas por ambos os pensadores divergem de forma notável: enquanto a benjaminiana aposta no poder transfigurador da arte mediante a possível criação de novas formas de vida coletiva pela práxis revolucionária, o enfoque determinante da teoria estética de Adorno recai sobre a subjetividade do indivíduo isolado. De modo a podermos dizer que o sujeito histórico não deixa jamais de ser, para Adorno, sujeito individual: indivíduo - ou o que ainda resta dele - em sua singularidade concreta e histórica.

Sobre esta diferença de perspectiva assinalada, gostaríamos, para terminar, de fazer duas breves observações.

Em primeiro lugar, cumpre não perder de vista que aqui comparamos teorias estéticas que maturaram sob contextos históricos bastante diversos: a de Benjamin, datada da década de 1930; a do último Adorno, da década de 1960. Três décadas de distância separam estas formulações, e três décadas que deram lugar a acontecimentos descomunais. Convém lembrar que, quando escreve sua Teoria Estética, Adorno já tinha vivido o bastante para saber que as esperanças

${ }^{51}$ Cf. WigGershaus, Rolf. L'Ecole de Francfort: Histoire, développement, signification. Paris: Puf, 1993, p. 625.

${ }^{52}$ A respeito dos motivos presentes na Teoria Estética de Adorno que não negam sua marca de nascença benjaminiana, ver o estudo já mencionado: ChiARELLo, M. Natureza-Morta: Finitude e negatividade em T. W. Adorno (p. 24). 
revolucionárias acalentadas por muitos pensadores nos anos 30 (Benjamin e o próprio Adorno entre eles), não só terminaram por não se concretizar, como deram lugar aos horrores da Segunda Grande Guerra e da Shoah. Adorno também pôde viver o suficiente para constatar que a aposta benjaminiana no potencial emancipador da arte de massas terminou por não se confirmar, assumindo, a seu ver, a forma reacionária da indústria cultural. Quanto a Benjamin, incapaz de atender ao imperativo de auto conservação em tempos extremamente conflituosos, sucumbiu à Guerra em seus começos. Assim, não pôde conhecer por completo os horrores que pressagiava e tampouco seu desfecho: lamentavelmente, antes de poder conhecê-los à distância e em segurança, ele os sofreu na própria carne.

Em segundo lugar, para ser justo com o pensamento adorniano, devemos reconhecer que, em seus últimos escritos, Adorno não recrimina toda e qualquer forma de práxis, mas sim a práxis degenerada em mero ativismo, isto é, a práxis exercida de forma compulsiva e sem reflexão crítica. O que se lhe afigura censurável é a práxis desvinculada da teoria, e até mesmo avessa à teoria, pois a dissociação entre teoria e práxis produz, de um lado, a impotência prática da teoria e, de outro, a cega compulsão do ativismo, que se coloca a um passo da violência irrefletida.

Ao mesmo tempo, Adorno avalia que, no momento histórico em que escreve (referimo-nos aqui à década de 1960), a práxis se encontrava condenada a assumir a forma desvirtuada do mero ativismo tático. Para ele, a via da práxis se mostrava, então, interditada, sendo por isso necessário resistir a seu apelo. Quando lemos, por exemplo, as suas Notas marginais sobre teoria e práxis, trabalho de 1969 que pretende conjugar a especulação filosófica com a experiência em sentido pleno, constatamos que Adorno não está muito longe de afirmar, numa formulação dialética paradoxal, que a boa práxis é a teoria, mais exatamente a teoria social eivada pela liberdade de pensamento e pela livre expressão artística. Afinal, a práxis em sua forma justa seria aquela que não recusasse o apelo da teoria e adotasse o lema: "pensar é um agir, teoria é uma forma de práxis". ${ }^{53}$ Teoria, assim, vista como uma outra forma de práxis, que não a forma atual, degenerada em mero ativismo tático. E, um pouco mais adiante: "Nesta medida, a arte é crítica da práxis enquanto não liberdade". ${ }^{54}$ Teoria, portanto, não como pura abstração conceitual, mas como atividade vivificada pela concretude vital, vale dizer, eivada pela autêntica experiência estética. Seria esta a teoria requerida, aquela que se exerce avizinhada à arte como uma nova forma de

\footnotetext{
${ }^{53}$ AdORno, T. W. Palavras e Sinais, op. cit., p. 204; AdORno, T. W. Consignas, op. cit., p.161. Do ensaio "Notas marginais sobre teoria e práxis".

${ }^{54}$ Idem, p. 206; idem, p. 162.
} 
práxis, liberta da compulsão do ativismo pretensamente revolucionário, e por isso efetivamente emancipadora.

Portanto, antes teoria que práxis pura e simplesmente; mas teoria que se avizinha da arte como nova forma de práxis. Arte, porém, como experiência estética em última instância subjetiva, em que o indivíduo isolado se abre para o coletivo social, nele se reencontra e se fortalece, recuperando uma identidade que se perdia. $\mathrm{E}$ não como experiência transfiguradora que se conjuga com a práxis coletiva, na qual o indivíduo prazenteiramente se perde, abandonando sua soberania subjetiva. Sim, pois, para o último Adorno, diferentemente de Benjamin, a experiência estética fundamental seria aquela que, compelindo o indivíduo (que vai sendo liquidado em seu isolamento) a se abrir para o coletivo, em busca de novas formas de organização social, possuiria o condão de salvá-lo numa totalidade reconciliada por vir. 


\section{Bibliografia}

ADORNO, Theodor Wiesengrund. Consignas (trad. Ramón Bilbao). Buenos Aires: Amorrortu, 1973 [Stichworte: Kritische Modelle 2].

Correspondência 1928-1940 / Adorno-Benjamin (trad. José Marcos Mariani de Macedo). São Paulo: Editora Unesp, 2012

Dialéctica Negativa (trad. José María Ripalda). Madri: Taurus, 1984

[Negativ Dialektik].

Filosofia da Nova Música (trad. Magda França). São Paulo: Perspectiva, 1989 [Philosophie der neuen Musik].

Minima Moralia: Reflexões a partir da vida danificada (trad. Luiz Eduardo

Bicca). São Paulo: Ática, 1993 [Minima Moralia: Reflexionen aus dem beschädigten Leben].

Palavras e Sinais: Modelos Críticos 2 (trad. Maria Helena Ruschel). Petrópolis: Vozes, 1995 [Stichworte. Kritische Modelle 2].

Prismas: Crítica cultural e sociedade (trad. Augustin Wernet e Jorge Mattos Brito de Almeida). São Paulo: Ática, 1998 [Prismen: Kulturkritik und Gesellschaft]. Sur Walter Benjamin (trad. Christophe David). Paris: Gallimard, 2001 [Über Walter Benjamin].

Teoria Estética (trad. Artur Morão). São Paulo: Martins Fontes/Edições 70, 1988 [Ästhetische Theorie].

AdORNo, Theodor Wiesengrund \& HoRkHEIMER, Max. Dialética do Esclarecimento: Fragmentos filosóficos (trad. Guido Antônio de Almeida). Rio de Janeiro: Zahar, 1985 [Dialektik der Aufkärung: Philosophische Fragmente].

Temas básicos de sociologia. São Paulo: Cultrix, 1973.

AlVES JR., Douglas Garcia. "Adorno e a instabilidade do sujeito", Pulsional, n. 176, ano XVI, dezembro/2003, pp. 5-9.

BAUMAN, Zygmunt. Identidade: Entrevista a Benedetto Vecchi. Rio de Janeiro: Zahar, 2005.

ChIARELlo, M. Natureza-morta: Finitude e negatividade em T.W. Adorno. São Paulo: Edusp, 2006.

DAMIÃO, Carla Milani. Sobre o declínio da "sinceridade": Filosofia e autobiografia de Jean-Jacques Rousseau a Walter Benjamin. São Paulo: Loyola, 2006.

FREITAS, Verlaine. "A arte moderna como historicamente-sublime: Um comentário sobre o conceito de sublime da Teoria Estética de T.W. Adorno", Kriterion, no. 127, jun/2013, p. 157-176.

"Alteridade e transcendência: A dialética da arte moderna em Theodor

Adorno". In DUARTE, Rodrigo; FIgUeIREdo, Virgínia; KANGUSSU, Imaculada. Theoria Aesthetica: Em comemoração ao centenário de Theodor W. Adorno. Porto Alegre: Escritos, 2005, pp. 45-56.

FRÜCHTL, Josef. Mimesis: Konstellation eines Zentralbegriffs bei Adorno, Würzburg: Konigshausen Neumann, 1986. 
GAGNEBIN, Jeanne Marie. "Atenção e dispersão: elementos para uma discussão sobre arte contemporânea a partir de Adorno e Benjamin". In Limiar, aura e rememoração: Ensaios sobre Walter Benjamin, São Paulo: Editora 34, 2014.

GATTI, Luciano. "Correspondências entre Benjamin e Adorno", Revista Limiar, vol. 1, n. 2, 2014, pp. 1-47.

HORKHEIMER, Max. "O pensamento de Schopenhauer em relação com a ciência em a religião", Cadernos de Tradução, n. 12, 2008.

KANT, Immanuel. Crítica da Razão Prática (trad. Artur Morão). Lisboa: Edições 70, 1994.

SAFATLE, Vladimir. A Paixão do Negativo: Lacan e a dialética. São Paulo: Editora Unesp, 2005. 2006, pp. 151-191.

"A teoria das pulsões como ontologia negativa", Revista Discurso, n. 36, . "Espelhos sem imagens: Mimesis e reconhecimento em Lacan e Adorno", Trans/Form/Ação, 28(2), 2005, pp. 21-45.

SCHWEPPENHÄUSER, Gerhard. "Zur Dialektik der Subjektivität bei Adorno", Zeitschrift für kritische Theorie, vol. 4, abril, 1997.

SCHWEPPENHÄUSER, Hermann. "Das Individuum in Zeitalter seiner Liquidation: über Adornos soziale Individuationstheorie". In: Vergegenwärtigungen zur Unzeit? Lüneburg: Klampen Verlag, 1986.

WAIZBORT, Leopold. "Sacrifício e liquidação do sujeito: Notas sobre a sociologia da música em Adorno". Revista Tempo Social, 2 (2), 1990, pp. 145-164.

WELSCH, Wolfgang. "Adornos Ästhetik: eine implizite Ästhetik des Erhabenen". In .̈̈sthetisches Denken. Stutgard: Reclam, 1993, pp. 114-156.

Wiggershaus, Rof. L'Ecole de Francfort: Histoire, développement, signification (tradução de Lilyane Deroche-Gurcel). Paris: Puf, 1993 [Die Frankfurter Schule]. 